${ }^{3}$ Griffiths RG. The abilities of young children. High Wycombe: The Test Agency, 1970.

${ }^{4}$ Ross G, Lipper EG, Auld PAM. Consistency and change in the development of premature infants weighing less than 1,501 grams at birth. Pediatrics 1985;76:885-9.

\section{Gonadal function after testicular radiation for acute lymphoblastic leukaemia}

Sir,

We were interested to read the recent paper by Leiper $e t$ al about the effect of direct testicular irradiation on Leydig cell function in boys treated for acute lymphoblastic leukaemia. ${ }^{1}$ The questions they attempted to answer are important ones. We need to know if Leydig cell vulnerability to radiation damage is age related and if such damage is reversible with time.

In our own study, published early last year, the results showed that six of the seven boys irradiated during prepubertal life had an absent testosterone response to human chorionic gonadotrophin stimulation. ${ }^{2}$ Two of the four boys irradiated during puberty had an appropriate basal testosterone concentration, but the testosterone response to human chorionic gonadotrophin stimulation was subnormal in three of the four. Thus we suspect that the Leydig cells of the pubertal testis may be less vulnerable to radiation damage than those of the prepubertal testis. We do not have sufficient data to indicate if age, as distinct from pubertal state, might influence the degree of testicular damage.

We found evidence that severe Leydig cell damage was present irrespective of whether the boys were studied within one year or between three and five years after irradiation, suggesting that recovery is unlikely. We note that in the seven boys studied sequentially by Leiper $e t a l,{ }^{1}$ five showed no improvement in Leydig cell function, while two had subnormal peak testosterone concentrations of $4 \cdot 6$ and $6.8 \mathrm{nmol} / \mathrm{l}(1.33$ and $1.96 \mathrm{ng} / \mathrm{ml})$, respectively, after human chorionic gonadotrophin stimulation. The basal testosterone concentration may well have been adequate for pubertal development to occur in these boys, but unless there is a further improvement in Leydig cell function they will both probably require androgen replacement therapy once puberty is completed to allow normal libido and sexual performance and to avoid osteoporosis.

$\mathrm{S}$ M Shalet and $\mathrm{P}$ H Morris-Jones Christie Hospital and Royal Manchester Children's Hospital, Manchester

Drs Leiper, Grant, and Chessells comment:

We welcome the comments of Shalet and Morris-Jones in response to our paper. ${ }^{1}$ We agree that it is important to know if Leydig cell vulnerability to radiation is age related and if such damage is reversible with time.
In their paper Shalet et al documented severe Leydig cell damage after testicular irradiation. This was irrespective of whether subjects were studied within one year or between three and five years from the time of radiotherapy, suggesting that recovery of function is unlikely. ${ }^{2}$ Our findings were similar to this in the majority of boys studied. In two of the seven cases studied sequentially using the human chorionic gonadotrophin test, however, at least partial recovery was clearly shown. The two subjects mentioned were studied two and three years after irradiation, when they were aged 10.9 years (Tanner Stage I) and 10.6 years (Tanner Stage II), respectively. The first boy had a basal testosterone concentration of $1.1 \mathrm{nmol} / \mathrm{l}$ $(0.31 \mathrm{ng} / \mathrm{ml})$ rising to $4.6 \mathrm{nmol} / \mathrm{l}$ after a three day human chorionic gonadotrophin test, while the second had a basal concentration of $0.8 \mathrm{nmol} / \mathrm{l}(0.23 \mathrm{ng} / \mathrm{ml})$ rising to 6.8 $\mathrm{nmol} / \mathrm{l}$. The testosterone responses after human chorionic gonadotrophin stimulation in these two children only six months after irradiation were grossly inadequate. ${ }^{3}$ Plasma testosterone rose from a basal concentration of $0.5 \mathrm{nmol} / \mathrm{l}$ $(0.14 \mathrm{ng} / \mathrm{ml})$ to a peak of $1.7 \mathrm{nmol} / \mathrm{l}(0.49 \mathrm{ng} / \mathrm{ml})$ in the first boy and from 0.4 to $1.2 \mathrm{nmol} / 1(0.12$ to $0.35 \mathrm{ng} / \mathrm{ml})$ in the second. We acknowledge that there is a possibility that these children may need hormone supplementation in adult life for the reasons stated by Shalet and Morris-Jones in their letter, and vigilant follow up is mandatory.

With our present data on small numbers of subjects it is difficult to be sure that the degree of testicular damage sustained is age related rather than related to pubertal state at the time of radiotherapy. All our subjects were, however, prepubertal at the time of radiation. We are currently attempting to clarify this with further prospective studies.

\section{References}

1 Leiper AD, Grant DB, Chessells JM. Gonadal function after testicular radiation for acute lymphoblastic leukaemia. Arch Dis Child 1986;61:53-6.

2 Shalet SM, Horner A, Ahmed SR, Morris-Jones PH. Leydig cell damage after testicular irradiation for lymphoblastic leukacmia. Med Pediatr Oncol 1985;13:65-8.

${ }^{3}$ Leiper AD, Grant DB, Chessells JM. The effect of testicular irradiation on Leydig cell function in prepubertal boys with acute lymphoblastic leukaemia. Arch Dis Child 1983;58:906-10.

\section{Prophylaxis of febrile convulsions: searching for the best}

\section{Sir,}

As confirmed by Knudsen in Archives $^{1}$ and elsewhere, ${ }^{2}$ the short term prophylaxis with diazepam seems sufficiently effective, feasible, and advantageous. His considerable effort $^{1}$ in codifying the risk of recurrence (age being the most predictive factor, on the basis of natural history, for the longer time span in which the central nervous system is evolving) must be considered as another step toward personalising the prophylaxis.

The temperature of $38 \cdot 5^{\circ} \mathrm{C}$, however, can be a near uncontrollable level of fever, adding an unnecessary extra 